\title{
Investigating effects of deficit irrigation levels and fertilizer rates on water use efficiency and productivity based on field observations and modeling approaches
}

\begin{abstract}
Investigating the effects of optimized fertilizer and irrigation levels on water use efficiency and productivity of wheat crop at small farms is of great importance for precise and sustainable agriculture in Pakistan's irrigated areas. However, traditional farmer practices for wheat production are inefficient and unsustainable. This study aimed to investigate the effects of deficit irrigation and nitrophos fertilizer levels on bread wheat grain yield, yield parameters, nutrient use and water use efficiencies in bed planting wheat compared to traditional farmers' practices in the flat sowing method. The two-year field experiment followed a randomized complete block design of three replications, taking three irrigation treatments according to the requirement of crop estimated by CROPWAT model $(100 \%$ of $\mathrm{ET}_{\mathrm{C}}$ ), deficit irrigation $\left(80 \%\right.$ of $\mathrm{ET}_{\mathrm{C}}$ ), and deficit irrigation $60 \%$ of $\mathrm{ET}_{\mathrm{C}}$ and three nitrophos fertilizer treatments (farmer practice $120 \mathrm{~kg} \mathrm{~N} \mathrm{ha}^{-1}$, optimized $96 \mathrm{~kg} \mathrm{~N} \mathrm{ha}^{-1}$, and $84 \mathrm{~kg}$ $\mathrm{N} \mathrm{ha}^{-1}$ ) at different growth stages. Crop ET $\mathrm{E}_{\mathrm{C}}$ was calculated using the FAO CROPWAT 8.0 model from the last ten years (2003-2013) average climate data of the experimental station. The traditional farmer practice treatment was included as a control treatment with a flat sowing method compared with other sown-by-bed planter treatments. All treatments were provided with an equivalent amount of fertilizer at the basal dose. Before the first and second irrigation, top-dressing fertilizer was used in traditional farmers' treatment at the third leaf and tillering stages. It was applied in optimized treatments before the first, second, and third irrigation at the third leaf, tillering and shooting stages, respectively, under the bed planting method. The deficit level of irrigation $(80 \%$ of ETc) and optimized fertilizer (96 $\mathrm{kg} \mathrm{N} \mathrm{ha}^{-1}$ ) showed the optimum grain yield, nutrient use, and water use efficiencies, with $20 \%$ reduced irrigation water and fertilizer levels than traditional farming practice. The results suggest that bread wheat should be irrigated with $80 \%$ of $\mathrm{ET}_{\mathrm{C}}$ and applied $96 \mathrm{~kg} \mathrm{~N}$ $\mathrm{ha}^{-1}$ nitrophos fertilizer at the third leaf, tillering, and shooting stages to achieve higher grain yield and water and nutrient use efficiencies under bed planting.
\end{abstract}

Keywords: optimized treatments, split doses, CROPWAT, ETc, deficit irrigation, nutrient use efficiency, water use efficiency, irrigated areas, small farms, nitrophos fertilizer, water productivity
Volume 5 Issue 5 - 202I

\author{
Muhammad Rizwan Shoukat, 1,4 Muhammad \\ Shafeeque, ${ }^{2,3,4}$ Abid Sarwar, ${ }^{4,5}$ Kashif \\ Mehmood, ${ }^{4,7}$ Muhammad Jehanzeb Masud \\ Cheema ${ }^{6}$ \\ 'College of Water Resources and Civil Engineering, China \\ Agricultural University, Beijing 100083, China \\ ${ }^{2}$ Climate Lab, Institute of Geography, University of Bremen, \\ 28359 Bremen, Germany \\ ${ }^{3}$ International Water Management Institute (IWMI), Lahore, \\ 53700, Pakistan \\ ${ }^{4}$ Department of Irrigation and Drainage, Faculty of Agricultural \\ Engineering and Technology, University of Agriculture, Faisalabad, \\ 38040, Pakistan \\ ${ }^{5}$ Biological Systems Engineering Department, Washington State \\ University, Pullman, WA, 99164-6120, USA \\ ${ }^{6}$ Department of Land and Water Conservation Engineering, \\ Faculty of Agricultural Engineering and Technology, PMAS-Arid \\ Agriculture University Rawalpindi \\ ${ }^{7}$ Center for Development Research (ZEFc), University of Bonn, \\ Germany
}

\begin{abstract}
Correspondence: Muhammad Shafeeque, Climate Lab, Institute of Geography, University of Bremen, 28359 Bremen, Germany, International Water Management Institute (IWMI), Pakistan,Emailm.shafeeque@uaf.edu.pk
\end{abstract}

\begin{abstract}
Co-Correspondence: Muhammad Jehanzeb Masud Cheema, Department of Land and Water Conservation Engineering Faculty of Agricultural Engineering and Technology, PMAS-Arid Agriculture University Rawalpindi, Pakistan, Emailmjm.cheema@uaar.edu.pk
\end{abstract}

Received: October II, 2021 | Published: October 25, 202 I

\section{Introduction}

The agriculture sector plays a vital role in the agrarian-based economy of densely-populated Pakistan, contributing $18.9 \%$ to the Gross Domestic Product (GDP) and consuming $42.3 \%$ of the labor force. ${ }^{1}$ In PakistLan, bread wheat (Triticum aestivum L.) contributes $8.9 \%$ to agricultural value-added and $1.6 \%$ to GDP. Meanwhile, it is the main staple food item and the widely used grain variety. The country's total wheat production was 25.190 million tons from 8,740 thousand hectares for the financial year 2019-20. ${ }^{2}$ Given the developing economy and large population, sustainable and efficient production of wheat is necessary not only to support the economy but also to feed the ever-growing population.

In irrigated areas of Pakistan, bread wheat is planted using the drilling or spreading method in the Rabi season. Under the drilling method, seeds are drilled in rows while keeping a row-to-row distance of $22.5 \mathrm{~cm} .{ }^{3}$ The drilling method can be named bed planting when seeds are drilled on beds of specific geometry. The bed planting technology is instrumental in saving water along with numerous other advantages, including enhanced fertilizer performance, uniform water distribution, lower lodging, better crop stands, natural excess water drainage after rain, simple weed control, and increased yield. ${ }^{4-7}$ On the other hand, in the spreading method used by farmers, seeds are spread on the smoothed soil surface, followed by narrow cultivation. In Pakistan, wheat grain yield per hectare is still $65-70 \%$ lesser than that in other wheat-producing countries ${ }^{3,8,9}$ even though farmers use excessive amounts of irrigation ${ }^{10,11}$ and fertilizers to boost crop yield in flat sowing method.

Irrigation management problems are generally coupled with fertilizer management issues. ${ }^{12}$ Improper fertilization and watering are the leading causes of nitrogen leaching, usually after the irrigation, ${ }^{13,14}$ mainly when excessive irrigation water is applied..$^{15}$ High fertilizer levels, primarily synthetic fertilizer, are often used to achieve high yields and nutrient use efficiency (NUE); however, the increased application of fertilizer has not led to consistently higher yields of crops. ${ }^{16-19}$ Proper amounts of irrigation can minimize fertilizer losses, 
increase crop growth, and yield. ${ }^{20,21}$ According to previous research, irrigation plants under the maximum water requirements for crops have proven suitable for conserving water. Scientists use Irrigation water calculation models like AQUACROP and CROPWAT 8.0 to determine crop evapotranspiration, crop water requirements (CWR), and irrigation scheduling. ${ }^{22}$ The Food and Agriculture Organization (FAO) created these software programs to help irrigation engineers and agronomists perform standard calculations for water irrigation studies and manage and design irrigation schemes. ${ }^{23}$ As a result of global climate change, the agriculture sector has begun to address water scarcity in recent years. To effectively use the limited amount of available water for agriculture, agricultural practices and understanding of water productivity must be improved ${ }^{24}$ to increase WUE. A combination of deficit irrigation (DI) and optimized nitrogen fertilizer application to the crops can be the best possible strategy. ${ }^{25}$ In irrigated areas, several researchers have found that deficit irrigation was a reliable strategy. ${ }^{26-29}$

Under deficit irrigation, coupled with bed planting, crops are deliberately permitted to some degree of irrigation shortage throughout the growing season or at specific growth stages. ${ }^{30}$ Deficit irrigation is a water management strategy adopted to enhance Water Use Efficiency (WUE) with little effect on yield. ${ }^{31}$ It is essential to mention that deficit irrigation may reduce crop growth and grain yield, as biomass and harvest index are reduced. ${ }^{32,33}$ The impact of DI on the growth and productivity of various crops has been extensively studied. ${ }^{34,35} \mathrm{DI}$ is a successful strategy for increasing water use efficiency in many crops without causing a significant yield loss. ${ }^{25,36,37}$ Several studies indicate that interactions between the irrigation management strategies and fertilization supply levels affect the nitrogen utilization of crops and influence the crop yield. ${ }^{39,40}$ Therefore, it can be hypothesized that the application of deficit irrigation and defined fertilization levels can enhance the WUE and grain yield of the wheat crop when it is sown on beds.

Most farmers have small landholdings in Pakistan, i.e., $<5$ ha. ${ }^{41}$ Given the poor economic conditions of small farmers, they cannot afford costly irrigation systems such as sophisticated drip and sprinklers irrigation systems. ${ }^{42}$ Therefore, better and affordable irrigation and soil management schemes and technologies are needed to improve WUE and fertilizer utilization. In terms of technology, farmers widely adopt the innovative wheat bed planting method in irrigated areas. ${ }^{43}$ For management schemes, irrigation water and fertilizers need careful management to increase wheat production in irrigated regions. Ungauged flood irrigation (generally $250-300 \mathrm{~mm}$ ) and a typical $120 \mathrm{~kg} \mathrm{~N} \mathrm{ha}^{-1}$ dose are traditional farming practices for wheat sown on a flat surface in irrigated areas of Punjab province of Pakistan. ${ }^{3}$ For small farms, these practices must be optimized for the sustainable and efficient production of the wheat crop. Therefore, it is clear that irrigation water and $\mathrm{N}$ fertilizer require judicious management in irrigated areas to enhance the wheat grain yield. ${ }^{19}$

Several studies examined the effects of FAO CROPWAT modelbased irrigation levels on various crops in Pakistan. ${ }^{44-48}$ However, the combined effect of the CROPWAT model-based irrigation levels and various nitrophos fertilizers rates on bread wheat is still unclear under bed plantation at small farms in irrigated areas of Pakistan. The main objectives of the current study were (1) to examine the coupling effects of various nitrophos fertilizer rates and CROPWAT modelbased irrigation levels on the wheat grain yield, yield parameters, NUE, and WUE compared to the traditional farmers' practice; and (2) to optimize the irrigation level and nitrophos fertilizer rate for increasing the bread wheat grain yield under bed planting method. According to crop requirements, the recommended fertilizer and irrigation management practices might be used as a benchmark to develop sustainable and precision agriculture policies at small farms in irrigated areas.

\section{Materials and methods}

\section{Experimental site}

The experimental site is located at the farms of the Water Management Research Center (WMRC) ( $31^{\circ} 38.71 \mathrm{~N}, 73^{\circ} 01.27$ E) at an elevation of $184 \mathrm{~m}$ in Faisalabad, Punjab, Pakistan. At the experimental site (Fig. 1), the mean, maximum, and minimum annual temperatures were recorded at $24^{\circ} \mathrm{C}, 31.6^{\circ} \mathrm{C}$, and $17.6^{\circ} \mathrm{C}$, respectively. However, daily maximum summer temperature reaches up to $48^{\circ} \mathrm{C}$, and a daily minimum winter temperature touches $4.8^{\circ} \mathrm{C}$, respectively. The summer months start from April to October, whereas the winter season spans from November to March. The average precipitation in the study area is $386 \mathrm{~mm} \mathrm{yr}^{-1}$, with the majority $(60-75 \%)$ falling in the monsoon season (June to September) Figure 1. The soil is predominantly sandy loam, with low organic matter (usually decrease with increasing depth) and $\mathrm{pH}$ ranging from 7.0 to $8.5 .{ }^{49,50}$ There are no salinity problems in the area. The topsoil depth of $45 \mathrm{~cm}$ was found to have comparatively moderate nutrient concentrations. The physiochemical soil properties of the study area are shown in Table 1.

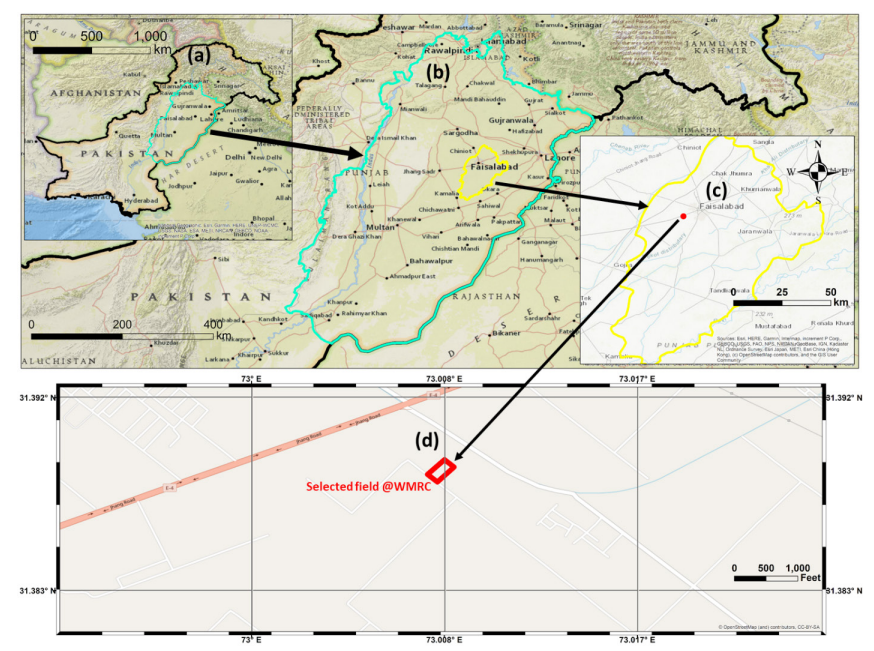

Figure I Location of the study area at Water Management Research Center (WMRC), Faisalabad, Punjab, Pakistan. (a) Pakistan, (b) Punjab, (c) Faisalabad, (d) selected field at WMRC.

Table I Soil physicochemical properties of the experimental site at WMRC Faisalabad

\begin{tabular}{llll}
\hline Properties & Depth $(\mathbf{c m})$ & \\
\hline & $\mathbf{0 - 3 0}$ & $\mathbf{3 0 - 6 0}$ & $\mathbf{6 0 - 9 0}$ \\
\hline Soil texture & Sandy loam & Sandy loam & Sandy loam \\
Bulk density $(\mathrm{g} \mathrm{cm}-3)$ & 1.44 & 1.47 & 1.48 \\
Porosity (\%) & 46 & 44 & 44 \\
Field capacity (\%) & 23.24 & 21.7 & 21.25 \\
Wilting point (\%) & 13.85 & 12.18 & 11.77 \\
Available water (\%) & 9.42 & 9.52 & 9.48 \\
EC (dS m-I) & 0.38 & 0.35 & 0.38 \\
PH & 8 & 7.9 & 8 \\
Organic matter (\%) & 0.56 & 0.35 & 0.31 \\
Nitrogen (\%) & 0.097 & 0.022 & 0.019 \\
\hline
\end{tabular}




\section{Details of experimental design and treatments}

A randomized complete block design (RCBD) two-year field experimental study with three replicates was designed and executed at a trial site during the Rabi season 2014-15 and 2015-16. Basic agricultural management operations, including rotavator, planking, and ploughing, were performed for land preparation before the sowing of bread wheat. A local bread wheat variety (AAS-2011) was sown on a flat surface using the broadcasting method in traditional farming (TFP) treatment. In contrast, the seed was directly sown in optimized treatments on beds (each of $0.6 \mathrm{~m}$ width with four rows of wheat) using a UAF-bed planter on the $10^{\text {th }}$ of November 2014 and $11^{\text {th }}$ of November 2015 in the two-year field experiment. The bedfurrow geometry is shown in Figure 2. The crop was harvested with a harvester in first- and second-year experiments upon maturity on the 15th of April 2015 and 17th of April 2016.

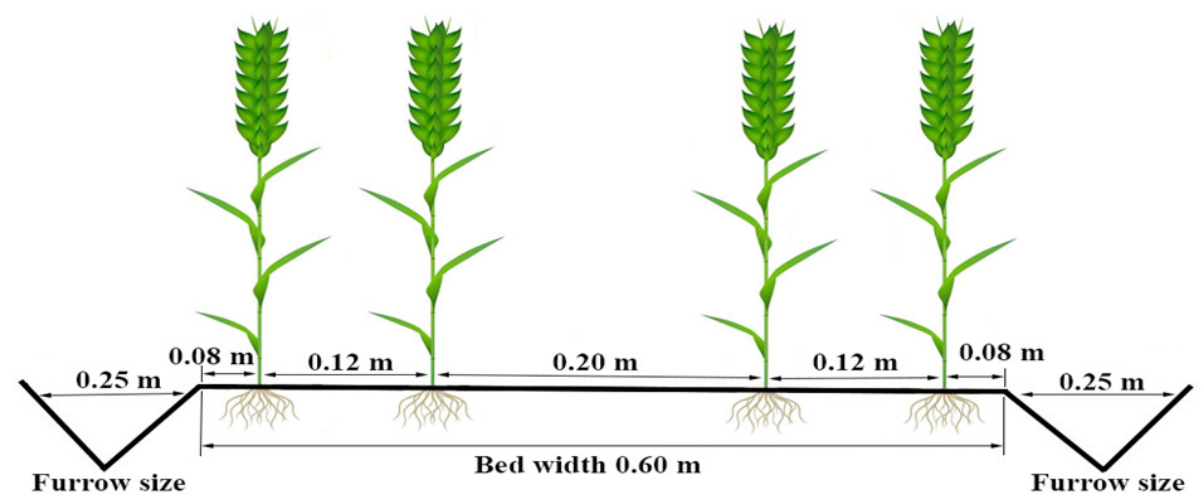

Figure 2 Bed and furrow geometry prepared by wheat bed planter under different irrigation and fertilizer treatments (T) at the experimental site.

In all the treatments, the basal dose of Muriate of Potash (MOP) $60 \mathrm{~kg} \mathrm{~K} \mathrm{ha}^{-1}$ was applied as a source of potassium. Sarsabz nitrophos fertilizer $(22 \% \mathrm{~N}$ and $20 \% \mathrm{P})$ was used as a basal dose by $40 \%$ in all treatments, and the remaining $60 \%$ applied as a top-dressing fertilizer in both year experiments. However, fertilizer in TFP treatment was used only $30 \%$ each, at the third leaf and tillering stages, the local farmer practice in the study area. According to the local area irrigation application for the wheat crop, FAO Crop irrigation model CROWAT based calculated $100 \%$ of the ETc (W100, $269 \mathrm{~mm}$ ) was considered TFP. Optimized irrigation treatments were included $80 \%$ of the ETc $\left(W_{80}, 215 \mathrm{~mm}\right)$ and $60 \%$ of the ETc $\left(W_{60}, 162 \mathrm{~mm}\right)$. In each irrigation treatment, $35 \%$ were irrigated at each the third leaf and tillering stages and $30 \%$ irrigated at the shooting stage during both year experiments. Fertilizer sources were nitrophos which is acidic fertilizer having $\mathrm{pH}$
3.5. The top-dressing fertilizer rate $100 \%$ TFP $\left(N_{100}, 120 \mathrm{~kg} \mathrm{~N}\right.$ ha $\left.{ }^{1}\right)$ was applied in two split applications, $30 \%$ each at the third leaf and tillering stages before $1^{\text {st }}$ and $2^{\text {nd }}$ irrigation. Optimized fertilizer treatments $80 \%$ of the TFP $\left(N_{80}, 96 \mathrm{~kg} \mathrm{~N} \mathrm{ha}^{-1}\right)$ and $70 \%$ of the TFP $\left(N_{70}, 84 \mathrm{~kg} \mathrm{~N} \mathrm{ha}^{-1}\right)$ were used in the split application $20 \%$ each at the third leaf, tillering and shooting stages, respectively before $1^{\text {st }}$, $2^{\text {nd }}$ and $3^{\text {rd }}$ irrigation. Irrigation water $100 \%$ of ETc and $100 \%$ of nitrogen fertilizer was considered a TFP practiced by farmers in the broadcasting method of wheat sowing in the experiments. TFP was based on the local average rate of $\mathrm{N}$ fertilization $\left(120 \mathrm{~kg} \mathrm{~N} \mathrm{ha}^{-1}\right)$ and irrigation water application $(270-350 \mathrm{~mm}$ per wheat season). TFP (control treatment) was designed for comparison with other optimized treatments in the two-year field experiment. Treatment combinations of the amount of irrigation and fertilizer are shown in Table 2.

Table 2 Treatment combinations of Irrigation amount and nitrophos fertilization rate. The letters ' $W$ ' and ' $N$ ' represent irrigation water and fertilizer levels, respectively

\begin{tabular}{llllll}
\hline Treatments & $\mathbf{W} \times \mathbf{N}$ & Irrigation & \multicolumn{3}{c}{ Fertilizer } \\
\hline TI (control) & $W_{100} N_{100}$ & 100 & 269 & 100 & 120 \\
T2 & $W_{100} N_{80}$ & 100 & 269 & 80 & 96 \\
T3 & $W_{100} N_{70}$ & 100 & 269 & 70 & 84 \\
T4 & $W_{80} N_{100}$ & 80 & 215 & 100 & 120 \\
T5 & $W_{80} N_{80}$ & 80 & 215 & 80 & 96 \\
T6 & $W_{80} N_{70}$ & 80 & 215 & 70 & 84 \\
T7 & $W_{60} N_{100}$ & 60 & 162 & 100 & 120 \\
T8 & $W_{60} N_{80}$ & 60 & 162 & 80 & 96 \\
T9 & $W_{60} N_{70}$ & 60 & 162 & 70 & 84 \\
\hline
\end{tabular}




\section{FAO CROPWAT 8.0 model description}

CROPWAT 8.0 is an FAO-developed decision-support computer program that uses rainfall, soil, crop, and environment data to measure reference evapotranspiration $\left(\mathrm{ET}_{0}\right)$, crop water requirement, irrigation scheduling, and irrigation water requirement. ${ }^{51}$ The software helps improve irrigation schedules and the simulation of crop water use for different crops under irrigated and rainfed conditions by providing general data for various crop features, local climate, and soil properties. It is based on FAO Irrigation and Drainage Paper $56 .{ }^{52}$

\section{Data requirements for CROPWAT}

Rainfall, climatic, soil, and crop data are required for the CROPWAT program. ${ }^{53}$ Rooting depth, crop coefficient, critical depletion, yield response factor, and duration of plant growth stages were all obtained from the experimental site during both years of the study and entered the CROPWAT software. ${ }^{22,23}$ Planting dates were determined based on wheat sowing dates in both seasons. The CROPWAT model provided soil parameters such as initial water depletion, maximum rainfall penetration rate, total water availability, and maximum rooting depth. Experimental Station's soil parameters for sandy loam soil were determined by the CROPWAT 8.0 model, including total available moisture content, initial moisture depletion, maximum rooting depth, and rainfall infiltration rate. In this analysis, the United States Department of Agriculture (USDA) soil conservation approach was used.22

\section{Reference evapotranspiration ( $\mathrm{ET}_{0}$ )}

The FAO Penman-Monteith equation (commonly known as the Penman-Monteith equation) is used in the CROPWAT model for $\mathrm{ET}_{0}$ estimation. Most of the data was measured from the climatic data.

$$
\text { ET } o=\frac{0.408 \Delta(\mathrm{Rn}-\mathrm{G})+\gamma \frac{900}{\mathrm{~T}+273} \mathrm{u} 2(\mathrm{es}-\mathrm{ea})}{\Delta+\gamma(1+0.34 \mathrm{u} 2)}
$$

Where $\mathrm{ET}_{0}$ is the reference evapotranspiration ( $\mathrm{mm} /$ day), $\mathrm{Rn}$ is the net radiation, $\mathrm{G}$ is the soil heat flux, $\gamma$ is psychometric constant, $\mathrm{T}$ is the mean daily air temperature $\left({ }^{\circ} \mathrm{C}\right)$ at $2 \mathrm{~m}$ height, $\mathrm{u} 2$ is the wind speed at $2 \mathrm{~m}$ height $\left(\mathrm{ms}^{-1}\right)$, es and ea are the saturation and actual vapor pressure $(\mathrm{kPa})$, respectively, and $\Delta$ is the slope of the relationship between saturation vapor pressure and air temperature.

\section{Crop water requirement (CWR) or evapotranspiration of the crop $\left(E T_{c}\right)$}

The crop water requirement is the quantity of water equivalent to what is lost from a cropped field by the ET and is represented by the rate of ET in $\mathrm{mm} /$ day. CWR is determined using crop evapotranspiration (ETc), which can be calculated using the equation below: ${ }^{54}$

$$
\mathrm{ETc}=\mathrm{Kc} \times \mathrm{ET}_{\mathrm{o}}
$$

where Kc represents the crop coefficient, and it is the ratio of the crop ETc to the $\mathrm{ET}_{0}$

\section{Data collection and measurement}

Last ten years (2003-13), meteorological data on maximum temperature, minimum temperature, average temperature, solar radiation, reference ET, precipitation for CROPWAT 8.0 model were collected from the repository of the weather monitoring station located near the experimental area (Figure 3). CROPWAT model estimated reference ET and solar radiation according to provided climatic data. ETc was calculated according to the last ten-year climatic data (20032013), shown in Figure 4. Daily climatic data during the two-year experiments were regularly monitored from sowing to the harvest of the wheat crop, as shown in Figure 5.

For irrigation applications in bed furrow and flat sowing, the total water depth of each flooding was measured for the wheat crop. During every irrigation, the discharge was measured using a cutthroat flume $(20 \mathrm{~cm} \times 92 \mathrm{~cm}$ in size $),{ }^{55}$ and the irrigation time was recorded using a stopwatch for each treatment. The amount of irrigation water was then determined from the time and discharge for the irrigation. ${ }^{56}$ The water depth was derived from the discharge, time, and irrigated area. ${ }^{57}$ The content of soil moisture was determined using the gravimetric method. ${ }^{58}$ Soil samples ( 3 samples per plot) were collected from soil depths of $0-30,30-60$ and $60-90 \mathrm{~cm}$ before and after each irrigation.

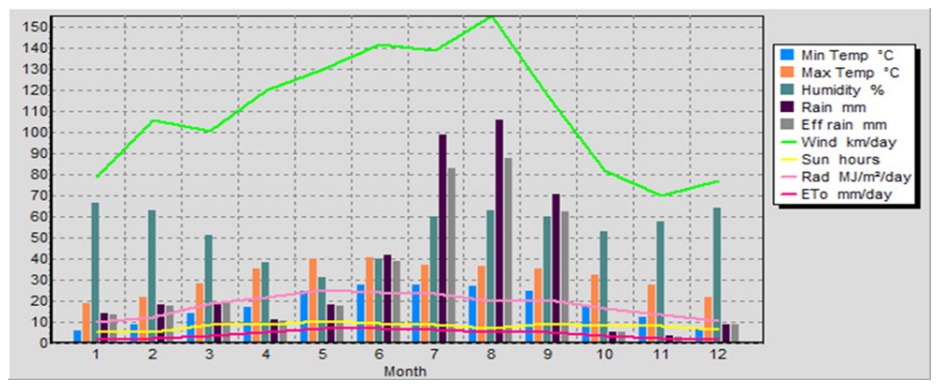

Figure 3 Average climatic data of study area from 2003 to 2013.

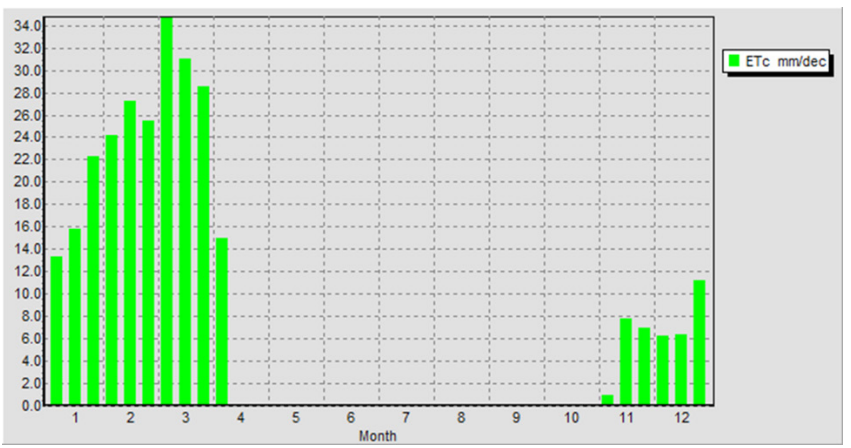

Figure 4 ETc of the wheat crop calculated by CROPWAT 8.0 from the mean climatic data of 2003-2013 of the experimental site.

Citation: Shoukat MR, Shafeeque M, Sarwar A, et al. Investigating effects of deficit irrigation levels and fertilizer rates on water use efficiency and productivity based on field observations and modeling approaches. Int J Hydro. 202I;5(5):252-263. DOI: I0.15406/ijh.2021.05.00287 


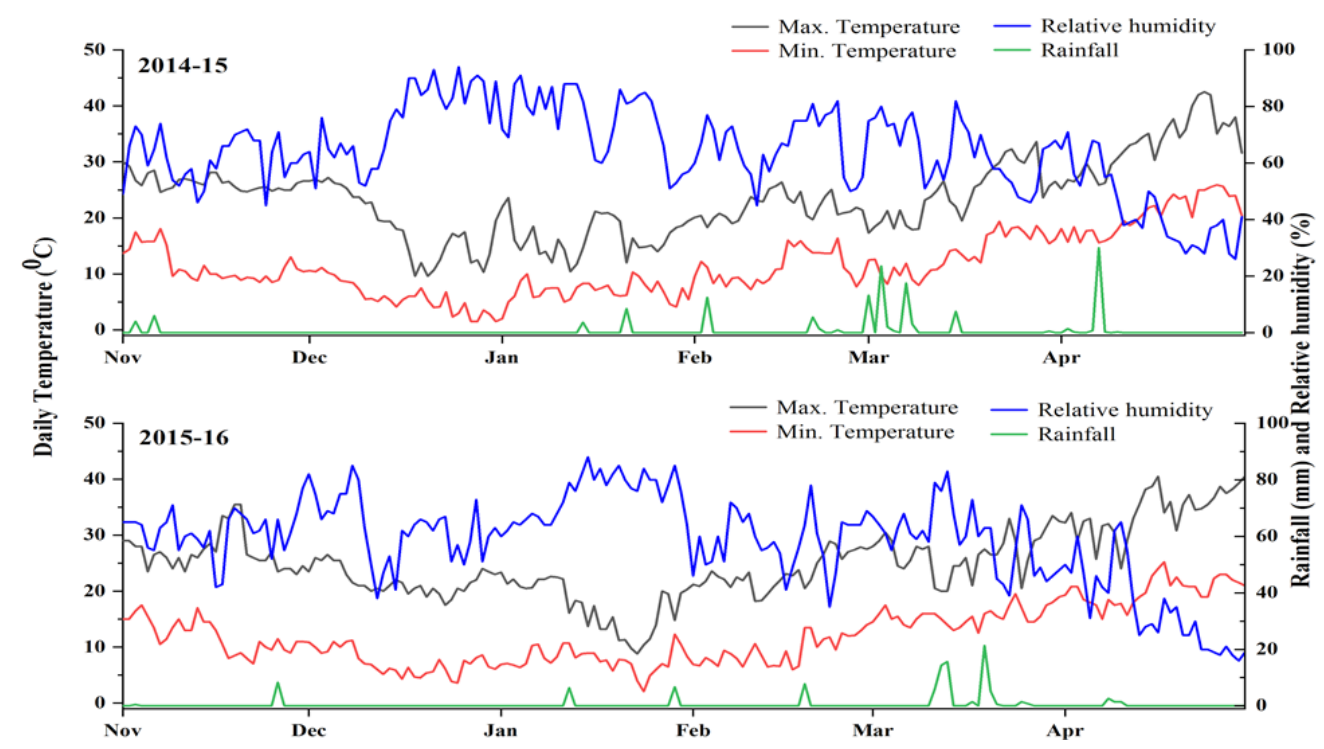

Figure 5 Daily weather data of 2014-15 and 2015-16 of experimental site monitored from sowing to harvest.

Twelve plant samples from each plot were chosen to determine plant height and yield components, such as the number of grains per spike, LAI, and spike length at the harvest. Grain yield (kg ha$\left.{ }^{1}\right)$, aboveground biomass $\left(\mathrm{kg} \mathrm{ha}^{-1}\right)$ and 1000 grain weight $(\mathrm{g})$ were calculated by taking the plant samples from $1 \mathrm{~m}^{-2}$ area at twelve different locations in each plot. Every experimental plot's grain yield was calculated by weighing grains after being naturally dried to a moisture content of 12 percent. The following equation was used to calculate the harvest index $(\mathrm{HI})$ :

$$
H I(\%)=\frac{\text { Grain yield }}{\text { Aboveground biomass }} \times 100
$$

where grain yield and aboveground biomass are in $\mathrm{kg} \mathrm{ha}^{-1}$.

\section{WUE and NUE measurement:}

The following relationship was used to calculate WUE $\left(\mathrm{kg} \mathrm{ha}^{-1}\right.$ $\left.\mathrm{mm}^{-1}\right):^{59}$

$$
W U E=\frac{Y}{E T c}
$$

where $Y$ is grain yield $\left(\mathrm{kg} \mathrm{ha}^{-1}\right)$ at maturity. ETc $(\mathrm{mm})$ is the total seasonal evapotranspiration during a period of wheat growth. ${ }^{60}$

The following formula was used to calculate NUE $\left(\mathrm{kg} \mathrm{kg}^{-1}\right)$ as described by Dobermann ${ }^{61}$ and: ${ }^{62}$

$$
\text { NUE } \frac{Y}{F}=
$$

where $\mathrm{Y}$ represents the wheat grain yield and $\mathrm{F}$ is the amount of fertilizer applied.

\section{Data analysis}

The collected data were analyzed by two-way analysis of variance (ANOVA) method using SPSS v26.0 software (IBM Corp., Chicago, IL, USA) to explore the meaning of irrigation and fertilizer treatment and their interaction effects on wheat grain yield and yield parameters as well as on WUE. The data were compared by using the Least Significance Difference (LSD) test at $P<0.05$.
The combined ranking of different treatments and their intercorrelations based on better outputs were derived using the Principal Component Analysis (PCA) by using Minitab software (Version 19.0, Minitab Inc., Enterprise Drive State College, PA, USA) ${ }^{63}$ PCA is a multivariate technique ${ }^{64}$ used to analyze data containing several intercorrelated quantitative dependent variables. It extracts the critical information from data and represents it using orthogonal variables known as principal components. The similarity patterns and intercorrelations of optimized level treatments, wheat grain yield, yield parameters, NUE and WUE have displayed score and loading plots. ${ }^{65}$

\section{Results}

\section{Effects of irrigation and nitrophos levels on yield and its components}

The effects of CROPWAT ETc based irrigation and $\mathrm{N}$ fertilization on grain yield and yield parameters were assessed at different water and fertilizer input levels in a two-year experiment. The yield components (Figure 6) and grain yield (Figure 7) under deficit irrigation (DI) were increased by nitrogen application. However, maximum results were obtained with the $\mathrm{W}_{80} \mathrm{~N}_{100}$ or $\mathrm{W}_{80} \mathrm{~N}_{100}$ treatments than other treatments. Both irrigation and $\mathrm{N}$ fertilization significantly affected the grain yield and its components (Table 3 ). When assessing the $\mathrm{N}$ fertilization and deficit irrigation levels treatment, the decrease in irrigation and $\mathrm{N}$ levels below a specific limit (below $80 \%$ of ETc and $80 \%$ of traditional farmer practice $\mathrm{N}$ application was observed in our two-year experiment) showed a significant decrease in yield and its components.

Nitrophos fertilizer applications to wheat plants grown at $80 \%$ ETc $\left(\mathrm{W}_{80} \mathrm{~N}_{80}\right.$ treatment) allowed the plants to produce growth characteristics close to those obtained with farmer practice fertilizer application $\left(\mathrm{N}_{100}\right)$. There were savings of fertilizer and irrigation water compared to traditional farmer practice $\left(\mathrm{W}_{100} \mathrm{~N}_{100}\right)$. Optimum plant height, spike length, 1000 grain weight, grains per spike, grain yield, and aboveground biomass were obtained in $\mathrm{W}_{80} \mathrm{~N}_{100}$ treatment, which has a non-significant difference at $\mathrm{P}<0.005$ with $\mathrm{W}_{80} \mathrm{~N}_{80}$ treatment. Compared to the control treatment $\left(\mathrm{W}_{100} \mathrm{~N}_{100}\right)$, TFP, in $\mathrm{W}_{80} \mathrm{~N}_{100}$ and $\mathrm{W}_{80} \mathrm{~N}_{80}$ treatments, $20 \%$ more grain yield was obtained in $2014-15$ and 
$21 \%$ in 2015-16 field experiments. The two-way analysis of variance found that irrigation and $\mathrm{N}$ fertilizer treatments significantly affect grain yield at $\mathrm{P}<0.05$. The interaction of irrigation and fertilizer treatments significantly affected the grain yield and their components. Taking into account the interaction impact of irrigation and nitrogen fertilization, statistically, treatment $\mathrm{W}_{80} \mathrm{~N}_{100}$ and $\mathrm{W}_{80} \mathrm{~N}_{80}$ showed optimal grain yield and yield components than other interaction levels during both growing seasons; both treatments have a non-significant difference at $\mathrm{P}<0.05$.
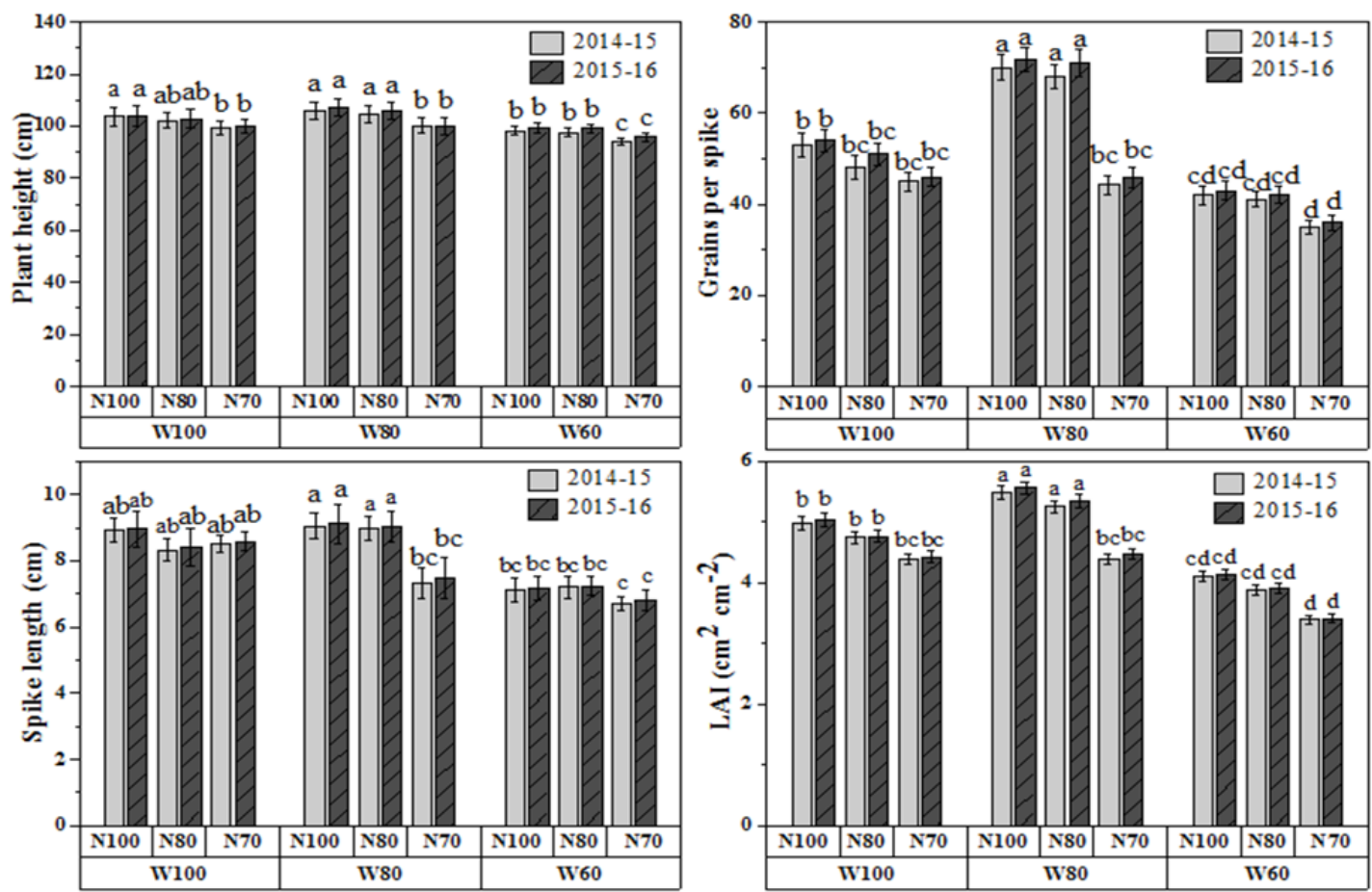

Figure 6 Effects of different levels of irrigation water and nitrophos rates on the yield-related components. Bars mean values with different letters significantly differ at the $P<0.05$ level of probability between treatments. The same letter represents values that are not significantly different at the $P<0.05$ level of probability according to the LSD test. Each value is the mean \pm SE $(n=9)$.
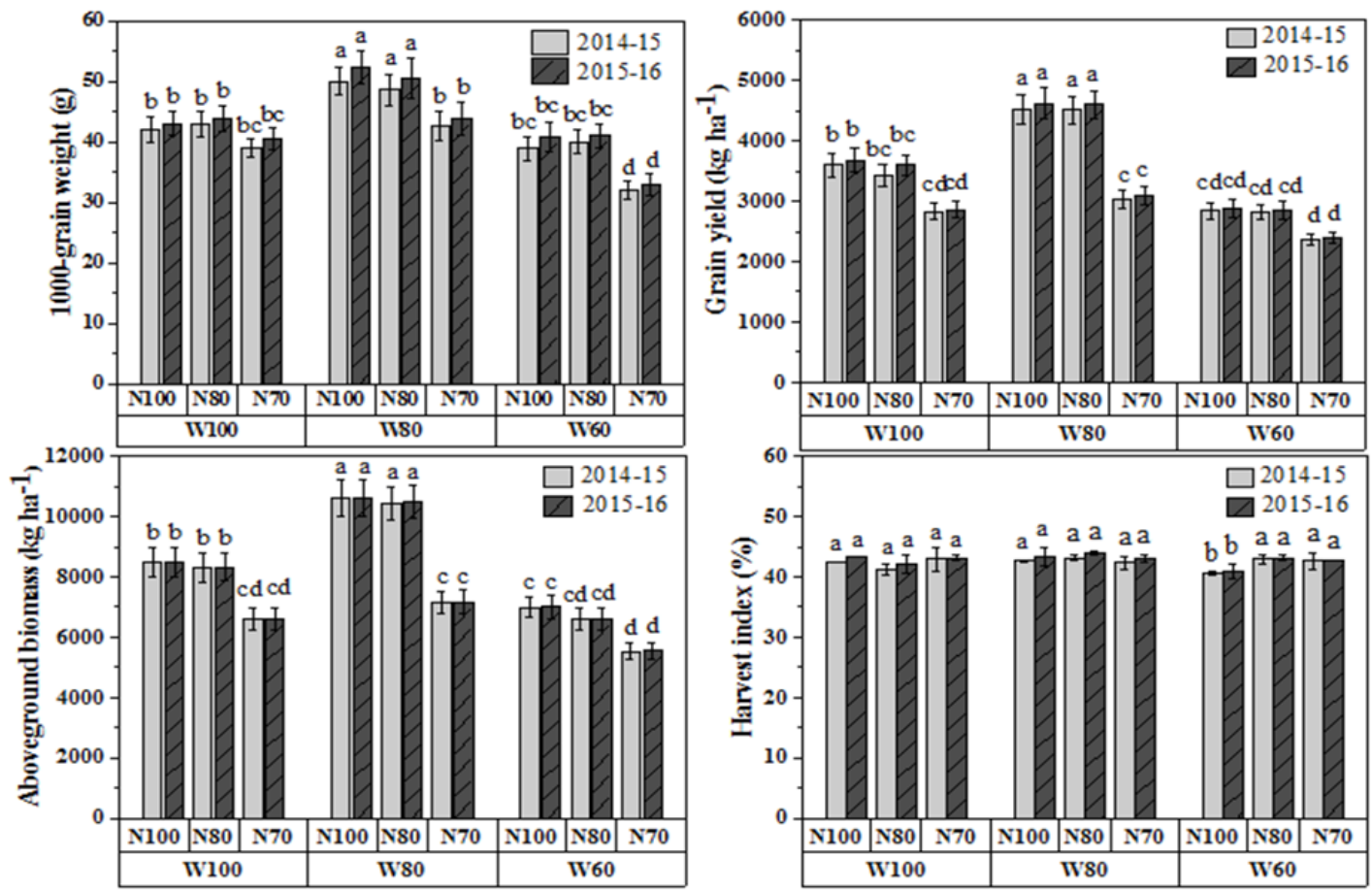

Figure 7 Effects of different levels of irrigation water and nitrogen rates on the wheat grain yield and its attributes. Bars mean values with different letters significantly differ at the $\mathrm{P}<0.05$ level of probability between treatments. The same letter represents values that are not significantly different at the $\mathrm{P}<0.05$ level of probability according to the LSD test. Each value is the mean \pm SE $(n=9)$.

Citation: Shoukat MR, Shafeeque M, Sarwar A, et al. Investigating effects of deficit irrigation levels and fertilizer rates on water use efficiency and productivity based on field observations and modeling approaches. Int J Hydro. 202 I;5(5):252-263. DOI: I0.I5406/ijh.202I.05.00287 
Table 3 Analysis of variance (ANOVA) of irrigation and fertilizer effects on grain yield, yield attributes, NUE, and WUE of bread wheat

\begin{tabular}{lllllllllll}
\hline Source of variation & \multicolumn{10}{c}{ Traits } \\
& PH & LAI & TGW & SL & GPS & GY & AGB & HI & NUE & WUE \\
\hline $\mathrm{W}$ & $* * *$ & $* * *$ & $* * *$ & $* * *$ & $* * *$ & $* * *$ & $* * *$ & $* * *$ & $* * *$ & $* * *$ \\
$\mathrm{~N}$ & $* * *$ & $*$ & $* * *$ & $* * *$ & $* *$ & $*$ & $\mathrm{~ns}$ & $\mathrm{~ns}$ & $* * *$ & $\mathrm{~ns}$ \\
$\mathrm{~W} \times \mathrm{N}$ & $*$ & $*$ & $* *$ & $* *$ & $* *$ & $\mathrm{~ns}$ & $\mathrm{~ns}$ & $\mathrm{~ns}$ & $*$ & $\mathrm{~ns}$ \\
\hline
\end{tabular}

*Significant at $\mathrm{P}<0.05$, **Significant at $\mathrm{P}<0.0 \mathrm{I}$, *** Significant at $\mathrm{P}<0.00 \mathrm{I}$, and ns, not significant, $\mathrm{P} \geq 0.05$. Where $\mathrm{PH}$ is plant height (cm), LAl is leaf area index $\left(\mathrm{cm}^{2} \mathrm{~cm}^{-2}\right)$, TGW is 1000 grain weight $(\mathrm{g}), \mathrm{SL}$ is spike length $(\mathrm{cm}), \mathrm{GPS}$ is grains per spike, GY is grain yield in $\left(\mathrm{kg}^{-1}\right), A G B$ is aboveground biomass $(\mathrm{kg}$ ha-1), $\mathrm{HI}$ is harvest index (\%), NUE is nutrient use efficiency $\left(\mathrm{kg} \mathrm{kg}^{-1}\right)$, and WUE is water use efficiency $\left(\mathrm{kg} \mathrm{ha}^{-1} \mathrm{~mm}^{-1}\right)$

\section{Effects of irrigation and $\mathbf{N}$ levels on water and nitrogen} use efficiency (WUE and NUE)

The effects of irrigation and fertilization on WUE and NUE were assessed at different water and fertilizer input levels, and it varied with varying treatments, as shown in Figure 8. ETc was measured using the FAO CROPWAT model under three different irrigation treatments $\mathrm{I}_{100}$, $\mathrm{I}_{80}$, and $\mathrm{I}_{60}, 269 \mathrm{~mm}, 215 \mathrm{~mm}$, and $162 \mathrm{~mm}$. The precipitation received during 2014-15 and 2015-16 was $133.4 \mathrm{~mm}$ and $102 \mathrm{~mm}$. The WUE was calculated using Eq. 4. The WUE was found significantly higher in $W_{80} N_{100}$ and $W_{80} N_{80}$ than TFP and other treatments. It was observed that WUE reduced when the irrigation level was lower than $215 \mathrm{~mm}$ ( $80 \%$ of ETc). The WUE was $31.86 \%$ and $32.44 \%$ higher in $W_{80} N_{100}$ and $W_{80} N_{80}$ treatments than in farmer practice treatment $T 1\left(W_{100} N_{100}\right)$ in 2014-15 and 2015-16. There was no significant difference $(P<$ $0.05)$ in WUE under $W_{80} N_{100}$ and $W_{80} N_{80}$; however, lesser fertilizer was applied in $W_{80} N_{80}$. The lowest WUE was observed under $W_{60} N_{70}$, which could be due to inadequate irrigation and fertilizer levels. The NUE was also affected under different fertilizer and irrigation treatments, and it was calculated using Eq. 5. Optimal NUE with maximum yield was observed in $W_{80} N_{80}\left(36 \mathrm{~kg} \mathrm{~kg}^{-1}\right)$ compared to other treatments, and it was $36 \%$ higher than TFP irrigation water and nitrogen application in both years of the experiment. The optimum levels of irrigation and fertilizer can significantly improve the WUE and NUE, whereas the inadequate levels could affect it negatively.

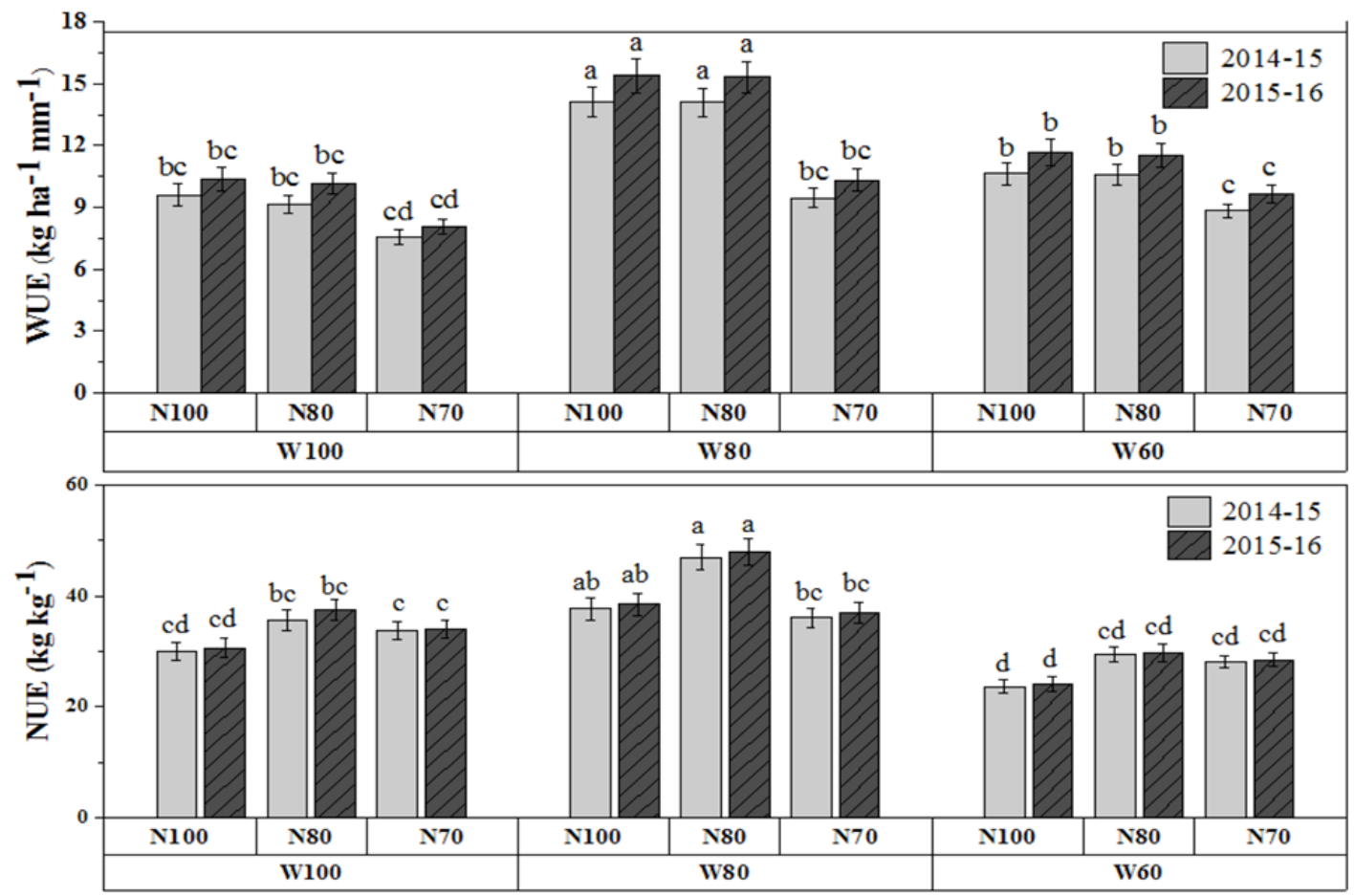

Figure 8 Effects of different levels of irrigation water and nitrophos rates on the WUE and NUE. Bars mean values with different letters significantly differ at the $\mathrm{P}<0.05$ level of probability between treatments. The same letter represents values that are not significantly different at the $\mathrm{P}<0.05$ level of probability according to the LSD test. Each value is the mean \pm SE $(n=9)$.

\section{PCA approach for evaluating the various treatments effects on crop yield and its attributes}

PCA showed that grain yield, yield components, NUE, and WUE positively correlated. The PCA first and second components contain the maximum variability of variability $(89.3 \%)$, while only the first component represents $79.3 \%$ variability in the observed data (Figure 5). The PCA score plot (Figure 9) showed the $\mathrm{T} 4\left(\mathrm{~W}_{80} \mathrm{~N}_{100}\right)$ and T5 $\left(\mathrm{W}_{80} \mathrm{~N}_{100}\right)$ positively correlated in the positive direction of the first component than other treatments. Most variability in the data was observed in the first component. In contrast, the $\mathrm{T} 9\left(\mathrm{~W}_{60} \mathrm{~N}_{70}\right)$ was negatively correlated in the first component of PCA. The PCA 
loading plot (Figure 10) highlighted that the optimized irrigation water and nitrogen levels of $T 4$ and $T 5$ showed positive effects on yield components, grain yield, NUE and WUE at small farms in irrigated areas. On the other hand, $T 9$ showed the minimum influence on the yield, yield components, NUE, and WUE. Based on the overall combined effects of optimized irrigation and fertilizer levels, the treatments were ranked as: $T 5>T 4>T 1>T 2>T 6>T 3>T 8>$ $T 7>T 9$.

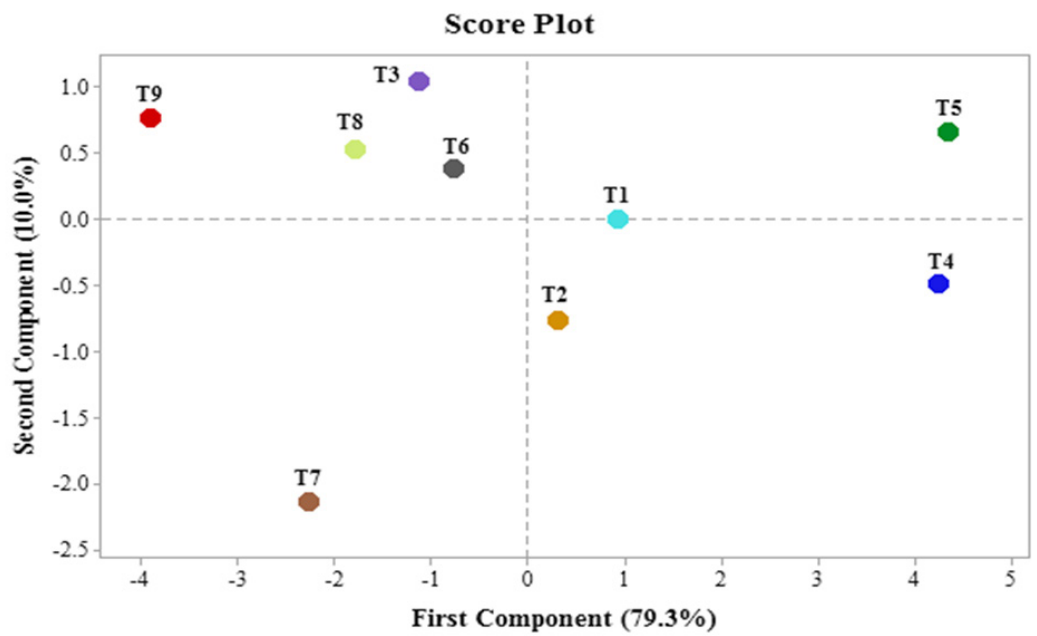

Figure 9 PCA score plot for various treatments of irrigation water and nitrogen rates.

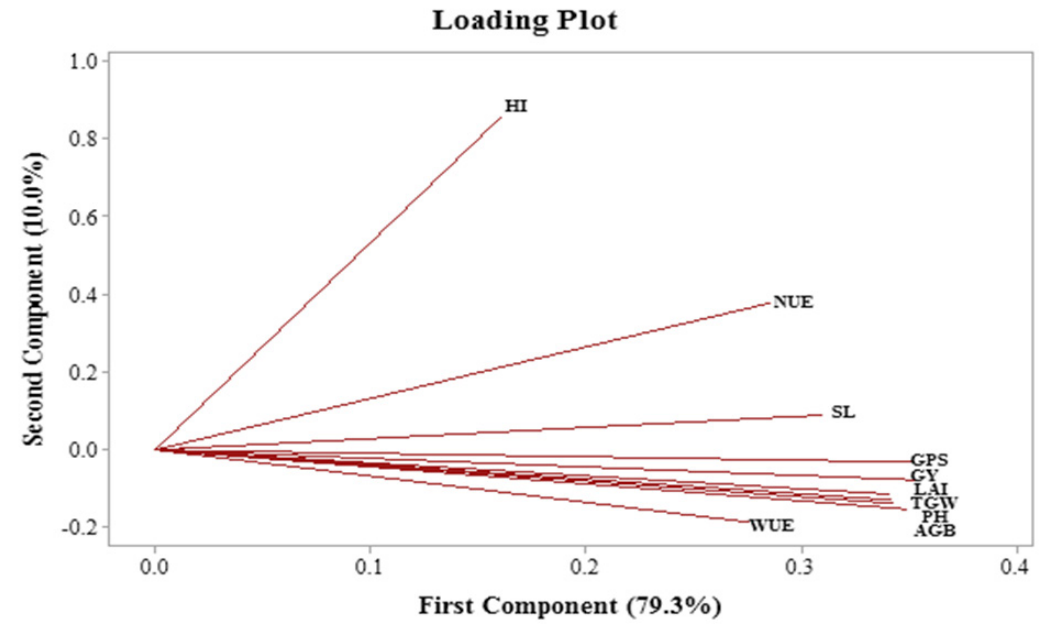

Figure 10 PCA loading plot for the effect of various treatments on grain yield, its parameters, WUE and NUE. HI indicate (harvest index), NUE (nutrient use efficiency), SL (spike length), GPS (grains per spike), GY (grain yield), LAI (leaf area index). TGW (I000-grain weight), PH (plant height), AGB (aboveground biomass) and WUE (water use efficiency).

\section{Discussion}

Two years of field research showed that optimized irrigation water and nitrophos fertilizer could increase the wheat grain yield under the bed plantation method. We examined the effects of CROPWAT $\mathrm{ET}_{\mathrm{C}}$-based irrigation and fertilizer levels on wheat grain yield, its parameters, NUE, and WUE under bed plantation compared to the farmer practice in flat sowing. Previous studies used the CROPWAT model to estimate crop water requirements in irrigated areas of Pakistan. ${ }^{44,46,66,67}$ However, the coupling effects of CROPWAT ETc based deficit irrigation levels and NP fertilizer rates are unclear for bread wheat under bed planting technique in irrigated areas of Pakistan. It was hypothesized that deficit irrigation based on CROPWAT ETc and optimized fertilizer application could improve grain yield, WUE, and NUE by saving water and fertilizer. We observed that the optimal amount of water and nitrogen fertilization significantly impacted growth parameters and grain yield, which is agreed well with. ${ }^{68,69}$
They examined that coupling optimal moisture conditions with fertilizer level can promote root growth, allowing plants to receive more nutrients from the soil, resulting in better plant growth and development. ${ }^{70}$ Under an open field, deficit watering with the optimal amount of fertilizer has been identified as a beneficial strategy for water $^{71}$ and fertilizer conservation at small farms in irrigated areas of Pakistan.

The maximum yield attributes (Figure 6) and wheat grain yield (Figure 7) were observed with higher nitrogen rates (100\% of TFP) and $80 \%$ of the total ETc based irrigation water application estimated by the FAO CROPWAT model. ${ }^{22}$ Statistically, there was no significant difference $(\mathrm{P}<0.005)$ was observed on grain yield and its parameters when 80 or $100 \%$ of the TFP nitrophos rates coupled with optimized irrigation ( $80 \%$ of total ETc) application. Our findings are in line with several other researchers, ${ }^{72-77}$ who concluded that $80 \%$ of ETc based deficit irrigation and reduced fertilization application than farmer 
practice can substantially increase grain yield, WUE, and NUE. Irrigation and fertilizer and their interaction significantly affected the grain yield, attributes, WUE, and NUE (Table 3). Several other researchers also observed similar results. ${ }^{78-80}$

The irrigation water and fertilizers should be applied at the proper time and in appropriate amounts to get the higher WUE and NUE with optimal grain yield. It highlighted that applying fertilizer in the three-split application ${ }^{81}$ rather than two split applications can be beneficial to obtain optimum grain yield. ${ }^{81-84} \mathrm{We}$ also found that grain yield and NUE did not always increase with enhancing the amounts of fertilizers, which is agreed well with the previous study. ${ }^{85,86}$ Furthermore, the lower dose of nitrophos $(70 \%$ of the farmer's practice in our experiment) and deficit irrigation (60\% of $\mathrm{ETc}$ ) resulted in minimum yield attributes, grain yield, WUE, and NUE. Excessive fertilizer and irrigation water application are used to enhance crop yield. However, we examined that higher fertilizer rates and irrigation application can reduce the grain yield, NUE, and WUE. An approach similar to ours has been presented before by other researchers ${ }^{87,88}$ Appropriate amounts of irrigation water and nitrogen fertilization rates are essential for optimal wheat development, and both have a significant impact on crop yield.

The maximum WUE ( $32 \%$ higher than TFP) was recorded at $80 \%$ of ETc based irrigation and full farmer practice fertilizer application (W80N100), which showed a non-significant $(\mathrm{P}<0.005)$ difference with the W80N80 treatment (Figure 8B). Ullah ${ }^{71}$ and ${ }^{89}$ also observed similar effects that $80 \%$ of ETc based deficit irrigation could be the optimal application for maximum grain yield and WUE without substantial yield reduction. The maximum NUE $36 \%$ higher than TFP) was observed when $80 \%$ of CROPWAT ETc based irrigation and $80 \%$ of farmer practice nitrogen were applied compared to other treatments (Figure 8A). Irrigation dynamics usually influence the efficiency of nitrogen usage by controlling its absorption mechanisms. Nitrogen in $\mathrm{NH}_{4}^{+}$and $\mathrm{NO}_{3}^{-}$is disbanded in water (present in a soil solution) and then passes from soil to roots, shoots, leaves, and other plant sections. Irrigation water, therefore, aids $\mathrm{N}$ plant uptake and directly correlates with $\mathrm{N}$-uptake and overall NUE. Reduced NUE under less irrigation $\left(60 \%\right.$ of ETc in our experiment) is in line with ${ }^{90}$ and ${ }^{91}$ findings. They found that irrigation water application impacts the plant nitrogen uptake and its accumulation process in grains. Therefore, an adequate level of irrigation water and nitrogen is advantageous for plant water and nutrient uptake ability at the same time, leading to their most effective as also observed by.

Reducing irrigation water and nitrogen level from a specified limit can negatively impact wheat yield and parameters. ${ }^{71}$ As a result, the various interactions of deficit irrigation and reduced nitrogen rates can be examined in the broader context in the future. PCA is a widely used method in modern data analysis and for exploring the interaction between various factors. Few researchers used it in field crop research (e.g., ${ }^{92,92}$ to evaluate the interaction between irrigation and fertilizer. A PCA's fundamental goal is to find patterns in data and explore correlations between variables. Our study used it to assess the relationship between treatments and various crop attributes. The results showed that the $\mathrm{W} 80 \mathrm{~N} 100$ and $\mathrm{W} 80 \mathrm{~N} 80$ treatments positively affected grain yield, yield parameters, WUE, and NUE. According to the score plot, T5 $\left(\mathrm{W}_{80} \mathrm{~N}_{80}\right)$ showed a more significant effect on crop yield than $\mathrm{T} 4\left(\mathrm{~W}_{80} \mathrm{~N}_{100}\right)$ or other treatments (Figure 9), and grain yield, yield components, WUE, and NUE are positively correlated in the loading plot (Figure 10). The optimal amount of fertilizer and irrigation level showed a substantial effect on grain yield. Several researchers have recommended applying optimized fertilizer rates ${ }^{92}$ and CROPWAT ETc based deficit irrigation (Li et al., 2018) for the maximum grain yield, NUE, and WUE.

Compared to two split applications of top-dressing fertilizer in TFP, three split nitrogen fertilizer applications in optimized treatments significantly improved grain yield under the bed planting technique. The findings of this study proposed that split applications of $\mathrm{N}$ fertilizer at three-leaf, tillering, and shooting stages before first, second and third irrigation could be an appropriate fertilization method to improve wheat growth and grain yield ${ }^{95} \mathrm{and}^{95}$ also found that split application of top-dressing fertilizer at critical stages of the crop can improve crop growth and grain yield. It is suggested that adopting the CROPWAT ETc based optimal deficit irrigation level and optimized nitrophos fertilizer rate can be the irrigation water and fertilizer saving practice to improve wheat grain yield in irrigated areas of Punjab Pakistan. The optimal use of irrigation water and synthetic fertilizers is inevitable to maintain the maximum crop productivity in the irrigated areas.

The strength of a two-year field study was that we successfully optimized the nitrophos fertilizer rate and irrigated level for bread wheat at a small farm in the irrigated area under the bed plantation method. We used the FAO CROPWAT model to estimate various irrigation levels based on the region's climatic conditions. According to the best of our knowledge, this is the first study to examine the coupling effects of optimized CROPWAT ETc based irrigation levels and nitrophos fertilizer rates on bread wheat at small farms in an irrigated region. However, Pakistan has twelve climatic zones based on rainfall and temperature variations. There is still room for improvement in optimizing irrigation water and macro and micronutrients for bread wheat under various climatic conditions. Therefore, further field and modeling studies are needed to confirm our results under other climatic zones in Pakistan.

\section{Conclusion}

Our field study findings show that this work offers a successful crop modeling approach to maximize the bread wheat grain yield with CROPWAT ETc based on deficit irrigation level and reduced fertilizers rate. In our study, deficit irrigation level ( $80 \%$ of ETc) and optimal fertilizer rate ( $80 \%$ of farmer practice) application at the third leaf, tillering and shooting stages under bed planation produced the higher grain yield with nutrients and water use efficiencies compared to farmer practice application. Therefore, we recommended that ETc based deficit irrigation level and reduced nitrophos fertilizer rate be applied at the third leaf, tillering, and shooting stages to maximize the bread wheat grain yield under bed planting compared to the flat sowing irrigated areas of Pakistan. The FAO CROPWAT model is beneficial in estimating crop irrigation water needs and developing the irrigation deficit levels for bread wheat. The present study was limited to Pakistan's study area climatic zone; however, it is suggested it could be extended for the other climate regions further to evaluate the effect of optimal level of irrigation and fertilizer rate on bread wheat.

\section{Acknowledgments}

The authors are grateful to the Water Management Research Center (WMRC), University of Agriculture, Faisalabad, Pakistan, for providing financial assistance and a research platform.

\section{Authors' contributions}

MRS and MS conceived the idea and designed the study. MRS conducted the fieldwork and collected the data. MRS, MS, and 
AS analyzed the data and prepared the manuscript. MRS, MS, AS, MJMC, and KM edited the manuscript.

\section{Conflicts of interest}

The authors declared no conflict of interest.

\section{References}

1. Rajpar H, Zhang A, Razzaq A, et al. Agricultural land abandonment and farmers' perceptions of land use change in the indus plains of Pakistan: A case study of Sindh province. Sustain. 2019;11:4663.

2. GOP G. of P. Pakistan Economic Survey Report 2018-19. Pakistan Econ. Surv. 1-23s. 2020

3. Majeed A, Muhmood A, Niaz A, et al. Bed planting of wheat (Triticum aestivum L.) improves nitrogen use efficiency and grain yield compared to flat planting. Crop J. 2015;3:118-124.

4. Choudhury BU, Bouman BAM, Singh AK. Yield and water productivity of rice-wheat on raised beds at New Delhi, India. F Crop Res. 2007;100:229-239.

5. Fahong W, Xuqing W, Sayre K. Comparison of conventional, flood irrigated, flat planting with furrow irrigated, raised bed planting for winter wheat in China. F Crop Res. 2004;87:35-42.

6. Govaerts B, Sayre KD, Ceballos-Ramirez JM, et al. Conventionally tilled and permanent raised beds with different crop residue management: effects on soil C and N dynamics. Plant Soil. 2006;280:143-155.

7. Hobbs PR, Sayre KD, Ortiz-Monasterio I. Increasing Wheat Yields Sustainably Through Agronomic Means. NRG Paper 98-01. Mex. DF CIMMYT. 1998

8. Mustafa A, Naveed M, Abbas T, et al. Growth response of wheat and associated weeds to plant antagonistic rhizobacteria and fungi. Ital $J$ Agron. 2019;14:191-198.

9. Sarwar N, Maqsood M, Mubeen K, et al. Effect of different levels of irrigation on yield and yield components of wheat cultivars. Pak J Agri Sci. 2020;47:371-374.

10. Mousavi SA, Shokuhfar A, Lak S, et al. Integrated application of biochar and bio-fertilizer improves yield and yield components of Cowpea under water-deficient stress. Ital J Agron. 2020;15:94-101.

11. Shafeeque M, Cheema MJM, Sarwar A, et al. Quantification of groundwater abstraction using SWAT model in Hakra branch canal system of Pakistan. Pakistan J Agric Sci. 2016;53.

12. $\mathrm{Hu} \mathrm{C}$, Saseendran SA, Green TR, et al. Evaluating nitrogen and water management in a double-cropping system using RZWQM. Vadose Zo J. 2006;5:493-505.

13. Li Y, Li J, Gao L, et al. Irrigation has more influence than fertilization on leaching water quality and the potential environmental risk in excessively fertilized vegetable soils. PLoS One. 2018;13:e204570.

14. Recio J, Vallejo A, Le-Noe J, et al. The effect of nitrification inhibitors on $\mathrm{NH} 3$ and $\mathrm{N} 2 \mathrm{O}$ emissions in highly $\mathrm{N}$ fertilized irrigated Mediterranean cropping systems. Sci Total Environ. 2018;636:427-436.

15. Gheysari M, Mirlatifi SM, Homaee M, et al. Nitrate leaching in a silage maize field under different irrigation and nitrogen fertilizer rates. Agric water Manag. 2009b;96:946-954.

16. Cui Z, Zhang F, Mi G, et al. Interaction between genotypic difference and nitrogen management strategy in determining nitrogen use efficiency of summer maize. Plant Soil. 2009;317:267-276.

17. Fang Q, Ma L, Yu Q, et al. Modeling nitrogen and water management effects in a wheat-maize double-cropping system. J. Environ. Qual. 2008;37:2232-2242.
18. Jiang $\mathrm{C}$, Lu D, Zu C, et al. One-time root-zone $\mathrm{N}$ fertilization increases maize yield, NUE and reduces soil $\mathrm{N}$ losses in lime concretion black soil Sci Rep. 2018;8:1-10.

19. Mon J, Bronson KF, Hunsaker DJ, et al. Interactive effects of nitrogen fertilization and irrigation on grain yield, canopy temperature, and nitrogen use efficiency in overhead sprinkler-irrigated durum wheat. $F$ Crop Res. 2016;191:54-65.

20. Khan S, Anwar S, Kuai J, et al. Optimization of nitrogen rate and planting density for improving yield, nitrogen use efficiency, and lodging resistance in oilseed rape. Front Plant Sci. 2017;8:532.

21. Mahajan G, Chauhan BS, Timsina J. Crop performance and water-and nitrogen-use efficiencies in dry-seeded rice in response to irrigation and fertilizer amounts in northwest India. F Crop Res. 2012;134:59-70.

22. Ewaid SH, Abed SA, Al-Ansari N. Crop water requirements and irrigation schedules for some major crops in Southern Iraq. Water. 2019;11:756.

23. Clarke D, Smith M, El-Askari K. CropWat for Windows: user guide. IHE. 2001.

24. Jones HG. Irrigation scheduling: advantages and pitfalls of plant-based methods. J Exp Bot. 2004;55:2427-2436.

25. Agami RA, Alamri SAM, Abd El-Mageed TA, et al. Role of exogenous nitrogen supply in alleviating the deficit irrigation stress in wheat plants. Agric Water Manag. 2018;210:261-270.

26. Abdalhi MAM, Jia Z. Crop yield and water saving potential for AquaCrop model under full and deficit irrigation managements. Ital J Agron. 2018;13:267-278.

27. Kirda C, Çetin M, Dasgan Y, et al. Yield response of greenhouse grown tomato to partial root drying and conventional deficit irrigation. Agric water Manag. 2004;69:191-201

28. Neal JS, Murphy SR, Harden S, et al. Differences in soil water content between perennial and annual forages and crops grown under deficit irrigation and used by the dairy industry. F Crop Res. 2012;137:148-162.

29. Patanè C, Cosentino SL. Effects of soil water deficit on yield and quality of processing tomato under a Mediterranean climate. Agric Water Manag. 2010;97:131-138.

30. Topçu S, Kirda C, Dasgan Y, et al. Yield response and N-fertiliser recovery of tomato grown under deficit irrigation. Eur J Agron. 2007;26:64-70.

31. Fereres E, Soriano MA. Deficit irrigation for reducing agricultural water use. J Exp Bot. 2007;58:147-159.

32. Bryant KJ, Benson VW, Kiniry JR, et al. Simulating corn yield response to irrigation timings: Validation of the EPIC model. J Prod Agric. 1992;5:237-242.

33. Stone PJ, Wilson DR, Reid JB, et al. Water deficit effects on sweet corn. I. Water use, radiation use efficiency, growth, and yield. Aust J Agric Res. 2001;52:103-113.

34. Agami RA. Alleviating the adverse effects of $\mathrm{NaCl}$ stress in maize seedlings by pretreating seeds with salicylic acid and 24-epibrassinolide. South African J Bot. 2013;88:171-177.

35. Agami RA, Ghramh HA, Hashem M. Seed inoculation with Azospirillum lipoferum alleviates the adverse effects of drought stress on wheat plants. J Appl Bot Food Qual. 2017;90:165-173.

36. Ballester C, Castel J, Abd El-Mageed TA, et al. Long-term response of 'Clementina de Nules' citrus trees to summer regulated deficit irrigation. Agric Water Manag. 2014;138:78-84.

37. Geerts S, Raes D. Deficit irrigation as an on-farm strategy to maximize crop water productivity in dry areas. Agric water Manag. 2009;96:12751284 
38. Sun H, Shen Y, Yu Q, et al. Effect of precipitation change on water balance and WUE of the winter wheat-summer maize rotation in the North China Plain. Agric Water Manag. 2020;97:1139-1145.

39. Wang X, Yang Y, Zhao J. Yield benefits from replacing chemical fertilizers with manure under water deficient conditions of the winter wheat - summer maize system in the North China Plain. Eur J Agron. 2021;119:126118.

40. Wang X, Xing Y. Evaluation of the effects of irrigation and fertilization on tomato fruit yield and quality: a principal component analysis. Sci Rep. 2017;7:1-13.

41. Hussain A, Thapa GB. Smallholders' access to agricultural credit in Pakistan. Food Secur. 2012;4:73-85.

42. Bell AR, Shah MAA, Ward PS. Reimagining cost recovery in Pakistan's irrigation system through willingness-to-pay estimates for irrigation water from a discrete choice experiment. Water Resour Res. 2014;50:66796695

43. Limon-Ortega A, Sayre KD, Francis CA. Wheat nitrogen use efficiency in a bed planting system in northwest Mexico. Agron J. 2000;92:303-308.

44. Ahmad M, Arshad M, Cheema M, et al. Comparison of available water resources for irrigation in Mithawan hill torrent command area of Dera Ghazi Khan, Pakistan. Pakistan J Agric Sci.2016;53.

45. Ahmed S, Masud Cheema MJ, Ahmed W, et al. Delineation of Hydrological Response Units to estimate water demand of canal command in Lower Chenab Canal using GIS modeling. Pakistan J Agric Sci. 2018;55.

46. Farooq N, Gheewala SH. Assessing the impact of climate change on sugarcane and adaptation actions in Pakistan. Acta Geophys. 2020;68:1489-1503.

47. Muzammil M, Zahid A, Breuer L. Water Resources Management Strategies for Irrigated Agriculture in the Indus Basin of Pakistan. Water. 2020;12:1429.

48. Shakoor A, Arshad M, Ahmad R, et al. Development of groundwater flow model (MODFLOW) to simulate the escalating groundwater pumping in the Punjab, Pakistan. Pakistan J Agric Sci. 2018;55.

49. Ali A, Zia MS, Hussain F, et al. Efficacy of different methods of potassium fertilizer application on paddy yield, K uptake and agronomic efficiency. Pakistan J Agric Sci. 2005;42:1-2.

50. Manzoor Z, Awan TH, Ahmad M, et al. Effect of split application of potash on yield and yield related traits of basmati rice. J Anim Pl Sci. 2008;18:120-124.

51. Gabr MEls. Modelling net irrigation water requirements using FAOCROPWAT 8.0 and CLIMWAT 2.0: a case study of Tina Plain and East South ElKantara regions, North Sinai, Egypt. Arch. Agron Soil Sci. 2021;1-16.

52. Allen RG, Pereira LS, Raes D, et al. Crop evapotranspiration-Guidelines for computing crop water requirements-FAO Irrigation and drainage paper 56. Fao, Rome 300, D05109. 1998.

53. Muñoz G, Grieser J. Climwat 2.0 for CROPWAT. Water Resour Dev Manag Serv. 2006;1-5.

54. Allen RG, Pereira LS, Raes D, et al. Crop evapotranspiration-Guidelines for computing crop water requirements-FAO Irrigation and drainage paper 56. Fao, Rome 300, D05109. 1998.

55. Skogerbee GV, Bennett RS, Walker WR. Selection and installation of cutthroat flumes for measuring irrigation and drainage water. 1973.

56. Chauhdary JN, Bakhsh A, Engel BA, et al. Improving corn production by adopting efficient fertigation practices: Experimental and modeling approach. Agric water Manag. 2019;221:449-461.

57. El-Halim A. Impact of alternate furrow irrigation with different irrigation intervals on yield, water use efficiency, and economic return of corn. Chil J Agric Res. 2013;73:175-180.
58. Reynolds SG. The gravimetric method of soil moisture determination Part IA study of equipment, and methodological problems. J Hydrol. 1970;11:258-273.

59. Han H, Yan YRZ. Response of winter wheat grain yield and water use efficiency to deficit irrigation in the North China Plain. Emirates J Food Agric. 2017;971-977.

60. Wang X, Yang Y, Zhao J. Yield benefits from replacing chemical fertilizers with manure under water deficient conditions of the winter wheat - summer maize system in the North China Plain. Eur J Agron. 2021;119:126118

61. Dobermann A. Nutrient use efficiency-measurement and management. Fertil best Manag Pract. 2007;1.

62. Ashraf U, Salim MN, Alam S, et al. Maize growth, yield formation and water-nitrogen usage in response to varied irrigation and nitrogen supply under semi-arid climate. Turkish J F Crop. 2016;21:88-96.

63. Jabbar S, Abid M, Hu B, et al. Exploring the potential of thermosonication in carrot juice processing. J Food Sci Technol. 2015;52:7002-7013.

64. Aredes RS, Peixoto FC, Sphaier LA, et al. Evaluation of craft beers through the direct determination of amino acids by capillary electrophoresis and principal component analysis. Food Chem. 20121;344:128572.

65. Xu J, Cai H, Wang, et al. Exploring optimal irrigation and nitrogen fertilization in a winter wheat-summer maize rotation system for improving crop yield and reducing water and nitrogen leaching. Agric Water Manag. 2020;228:105904.

66. Bell AR, Shah MAA, Ward PS. Reimagining cost recovery in Pakistan's irrigation system through willingness-to-pay estimates for irrigation water from a discrete choice experiment. Water Resour Res. 2014;50:66796695.

67. Shakoor A, Arshad M, Ahmad R, et al. Development of groundwater flow model (MODFLOW) to simulate the escalating groundwater pumping in the Punjab, Pakistan. Pakistan J Agric Sci. 2018;55.

68. Si Z, Zain M, Mehmood F, et al. Effects of nitrogen application rate and irrigation regime on growth, yield, and water-nitrogen use efficiency of drip-irrigated winter wheat in the North China Plain. Agric Water Manag. 2020;231:106002

69. Xu J, Cai H, Wang, et al. Exploring optimal irrigation and nitrogen fertilization in a winter wheat-summer maize rotation system for improving crop yield and reducing water and nitrogen leaching. Agric Water Manag. 2020;228:105904.

70. Ashraf U, Salim MN, Alam S, et al. Maize growth, yield formation and water-nitrogen usage in response to varied irrigation and nitrogen supply under semi-arid climate. Turkish J F Crop. 2016;21:88-96.

71. Ullah I, Mao H, Rasool G, et al. Effect of Deficit Irrigation and Reduced N Fertilization on Plant Growth, Root Morphology, and Water Use Efficiency of Tomato Grown in Soilless Culture. Agronomy. 2021;11:228.

72. Chen Z, Liu X, Niu J, et al. Optimizing irrigation and nitrogen fertilization for seed yield in western wheatgrass [Pascopyrum smithii (Rydb.) Á. Löve] using a large multi-factorial field design. PLoS One. 2019;14:e0218599.

73. Ishaque $\mathrm{W}$, Abbas $\mathrm{F}$, Ali $\mathrm{S}$, et al. Yield response of wheat (Triticum aestivum L.) to deficit and regulated deficit irrigation under arid/semi-arid conditions. Pakistan J Agric Sci. 2017;54.

74. Mao XM, Zhong WW, Wang XY, et al. Effects of precision planting patterns and irrigation on winter wheat yields and water productivity. $J$ Agric Sci. 2017;155:1394

75. Maqsood M, Shehzad MA, Ahmed M. Seasonal growth attributes of wheat (Triticum aestivum L.) genotypes in response to moisture regimes under semi arid environment. Pak J Agri Sci. 2012;49:275-280.

76. Zhang Y, Wang $\mathrm{H}$, Lei Q, et al. Optimizing the nitrogen application rate for maize and wheat based on yield and environment on the Northern China Plain. Sci Total Environ. 2018;618:1173-1183. 
77. Zhang X, Meng F, Li H, et al. Optimized fertigation maintains high yield and mitigates $\mathrm{N} 2 \mathrm{O}$ and $\mathrm{NO}$ emissions in an intensified wheat-maize cropping system. Agric Water Manag. 2019;211:26-36.

78. Song F, Zhuge Y, Guo X. Optimizing irrigation and fertilization can improve degraded saline soils and increase wheat grain yield. L Degrad Dev. 2021;32:494-504.

79. Thapa S, Xue Q, Jessup KE, et al. Yield determination in winter wheat under different water regimes. F Crop Res. 2019;233:80-87.

80. Zhang Z, Zhang Y, Shi Y, et al. Optimized split nitrogen fertilizer increase photosynthesis, grain yield, nitrogen use efficiency and water use efficiency under water-saving irrigation. Sci Rep. 2021;10:1-14.

81. Talebbeigi RM, Kazemeini SA, Ghadiri H, et al. Split nitrogen sources effects on nitrogen use efficiency, yield and seed quality of safflower (Carthamus tinctorius L.). Ital J Agron. 2018;13:303-309.

82. Hou $\mathrm{P}$, Gao Q, Xie R, et al. Grain yields in relation to $\mathrm{N}$ requirement: Optimizing nitrogen management for spring maize grown in China. $F$ Crop Res. 2012;129:1-6.

83. Lü P, Zhang JW, Jin LB, et al. Effects of nitrogen application stage on grain yield and nitrogen use efficiency of high-yield summer maize. Plant Soil Environ. 2012;58:211-216

84. Tilman D, Cassman KG, Matson PA, et al. Agricultural sustainability and intensive production practices. Nature. 2002;418:671-677.

85. Jin L, Cui H, Li B, et al. Effects of integrated agronomic management practices on yield and nitrogen efficiency of summer maize in North China. F Crop Res. 2012;134:30-35.

86. Yao F, LI Q, ZENG R. Effects of different agricultural treatments on narrowing winter wheat yield gap and nitrogen use efficiency in China. $J$ Integr Agric. 2021;20:383-394.
87. Di Paolo E, Rinaldi M. Yield response of corn to irrigation and nitrogen fertilization in a Mediterranean environment. F Crop Res. 2008;105:202210.

88. Gheysari M, Mirlatifi SM, Bannayan M, et al. Interaction of water and nitrogen on maize grown for silage. Agric water Manag. 2009a;96:809821.

89. Attia A, El-Hendawy S, Al-Suhaibani N, et al. Evaluating deficit irrigation scheduling strategies to improve yield and water productivity of maize in arid environment using simulation. Agric Water Manag. 2021;249:106812.

90. Zand-Parsa S, Sepaskhah AR, Ronaghi A. Development and evaluation of integrated water and nitrogen model for maize. Agric Water Manag. 2016;81:227-256.

91. Mahbod M, Zand-Parsa S, Sepaskhah AR. Modification of maize simulation model for predicting growth and yield of winter wheat under different applied water and nitrogen. Agric Water Manag. 2015;150:1834

92. Porker K, Straight M, Hunt JR. Evaluation of $\mathrm{G} \times \mathrm{E} \times \mathrm{M}$ Interactions to Increase Harvest Index and Yield of Early Sown Wheat. Front Plant Sci. 2020;11:994.

93. Wang B, Zhang Y, Hao B, et al. Grain yield and water use efficiency in extremely-late sown winter wheat cultivars under two irrigation regimes in the North China Plain. PLoS One. 2016;11:e0153695.

94. Zeng S, Jacobs DF, Sloan JL, et al. Split fertilizer application affects growth, biomass allocation, and fertilizer uptake efficiency of hybrid Eucalyptus. New For. 2013;44:703-718.

95. Hu F, Tan Y, Yu A. Optimizing the split of $\mathrm{N}$ fertilizer application over time increases grain yield of maize-pea intercropping in arid areas. Eur $J$ Agron. 220;119:126117. 